\title{
Strong Correlation of MTHFR Gene Polymorphisms with Breast Cancer and its Prognostic Clinical Factors among Egyptian Females
}

\author{
Moataza H. Omran ${ }^{1 *}$, Basma E. Fotouh ${ }^{1}$, Wafaa G. Shosha ${ }^{2}$, Abeer Ismail ${ }^{3}$, \\ Noha E. Ibrahim ${ }^{1}$, Shimaa S. Ramadan ${ }^{2}$
}

\begin{abstract}
Introduction: Globally, Breast cancer $(\mathrm{BC})$ is considered the second most common type of cancer and the principal cause of death among affected women. Aim: In this study, we targeted to demonstrate the association of MTHFR single gene polymorphisms $(S N P S)$ with the susceptibility of breast cancer, in addition to its correlation with the clinical patient features. Patients and Methods: This work was conducted on 100 Egyptian females with breast cancer and 60 healthy matched controls. Clinical examinations and pathological investigations were recorded. Genotyping of MTHFR polymorphisms $C 677 T$ (rs1801133) and $A 1298 C$ (rs1801131) by using Restriction Fragment length Polymorphisms (RFLP) and Sequencing assays were performed. Univariate, Multivariate and Haplotype analysis for the allelic frequencies and the association with clinicopathological features of $\mathrm{BC}$ were assessed. Results: The present data showed a strong significant association between the CT and TT of MTHFR (C677T), and AC and CC of (A1289C) with the susceptibility of BC showing highly statistical P-value (0.001). It was also demonstrated that the most frequent haplotype of the two loci of MTHFR (rs1801133-rs1801131) was TC. The latter was strongly associated with the aggressive clinical features of each of tumor size, advanced stage, involvement of cancer in lymph nodes, overexpression of HER2neu and dual negativity of both ER and PR hormones. Conclusions: SNPs within the MTHFR gene (C677T) and (A1289C) have strong correlation with BC among Egyptian females; These SNPs should be considered as important prognostic markers for identifying the individuals at high risk of developing $\mathrm{BC}$ and its progression.
\end{abstract}

Keywords: Methylenetetrahydrofolate reductase - C677T-A1298C-single gene polymorohisms (SNPs)

Asian Pac J Cancer Prev, 22 (2), 617-626

\section{Introduction}

Worldwide, Breast cancer (BC) is considered a fundamental health problem and it is the principal cause of cancer death in females (Siegel et al., 2019). It is more common in developing countries. In Egypt, Carcinoma of the breast is the most prevalent cancer among Egyptian women representing about $35 \%$ of total cancer cases (Ibrahim et al., 2014). It has been shown that genetic factors interact with numerous environmental factors playing an important role in the pathogenesis of Breast cancer (Liu e al., 2016; Floris et al., 2020). Strong evidence by research revealed that folate metabolism imbalance plays a crucial role in cancer predisposition, based on its involvement in nucleic acid synthesis, methionine regeneration, oxidation and DNA synthesis (Carvalho et al., 2012).

Folate metabolism is controlled by several polymorphic genes. Methylenetetrahydrofolate reductase (MTHFR) gene is one of these several genes located on chromosome 1 and is the prime form of folate in plasma giving the methyl group for methionine synthesis affecting DNA profiles by mediating the irreversible conversion of 5, 10-methylenetetrahydrofolate $(5,10$-MTHF) to 5-methyltetrahydrofolate (5-MTHF) (crider et al, 2012; Castigilia et al., 2019). There are two functional and common single nucleotide polymorphisms (SNPS) in the MTHFR gene, C677T (rs 1801133) and A1298C (rs 1801131 ) that play a role in decreasing enzyme activity and increasing levels of plasma homo-cysteine (Castigilia et al., 2019; Floris et al., 2020). The C677T polymorphism takes place in exon 4, which involves a $\mathrm{C}$ to $\mathrm{T}$ substitution at position 677 , leading to the substitution of the amino acid alanine to a valine at codon 222 (Ala222Val) in the N-terminal catalytic domain. While, the MTHFR A1298C polymorphism, takes place in exon 7.This polymorphism results in changing the glutamic acid to alanine at codon 429 (Glu429Ala) in the C-terminal regulatory domain of

${ }^{1}$ Department of Microbial Biotechnology, Genetic Engineering Division, National Research Centre, Cairo, Egypt. ${ }^{2}$ Department of Chemistry, Faculty of Science, Helwan University, Cairo, Egypt. ${ }^{3}$ Department of Clinical and Chemical Pathology, National Cancer Institute, Cairo University, Giza,Egypt.*For Correspondence: moataza13@yahoo.com 
the protein (Weisberg et al., 2001; Waseem et al., 2016). Previous studies revealed the role of the interaction between these polymorphisms in the biosynthesis, repair and stability of DNA, causing abnormal gene expression, stimulating proto-oncogenes, over growth and aggressive cell transformation resulting in carcinogenesis (Kekeeva et al., 2006; Nazki et al., 2014).

Breast cancer might be invasive that grows into the surrounding tissues or noninvasive that does not grow beyond the lobules or the ducts of the breast. Ductal carcinoma represents the majority of breast cancer where the cancer spreads in the cells lining milk ducts (Rakha et al., 2010; Gorringe et al., 2017).

Breast cancer could be in early or advanced stages including stages I, II and III. These stages describe the cancer location, its extent of growth and spread. It might spread into the near lymph nodes or to distant parts of body as lungs, liver and bones( through blood and lymph vessels) that is called metastatic breast cancer (stage IV) (Veronesi et al., 2009; Donepudi et al., 2014).

In few studies, the association of the single nucleotide polymorphisms with the main clincopathological features of breast cancer has been proposed (Karimian et al., 2020). These SNPs have also been correlated with the increasing risk of other cancers as cervical cancer, ovarian cancer, lung cancer, pancreas cancer, prostate cancer (Xia et al., 2014; Hajiesmaeil et al., 2016; Moghaddam et al., 2016; Zhong et al., 2019).

Therefore, this work aims to study the association between MTHFR gene polymorphisms (C677T and A1298C) and the risk of developing breast cancer in Egyptian females. Furthermore, this is a prior study targets to clarify the linkage between the genetic basis of breast cancer and the appearance of aggressive clinical feature, providing a molecular basis for using these polymorphisms as markers for the modulation and the prognosis of breast cancer disease.

\section{Materials and Methods}

\section{Subjects and Methods}

Subjects (cases and controls)

This study was conducted on 100 Egyptian females cases who had been clinically and histologically proven to be breast cancer and 60 healthy control Subjects. Patients' clinicopathological data for each case were collected from their medical files at National Cancer Institute, Cairo University. The recorded information at diagnosis has the following inclusions: (1) age, (2) menopausal status, (3) family history, (4) Scarff-Bloom-Richardson (SBR) grade, (5) tumor size, (6) involvement of cancer in lymph node, (7) metastases, (8) histology type, (9) human epidermal growth factor receptor 2 (Her-2), (10) hormone receptor status including: estrogen receptor (ER) and progesterone receptor $(\mathrm{PR})$.

While, Exclusion criteria included: 1) Former history of any other types of cancer 2) Causes of infection by different viruses, 3) uncontrolled diabetes mellitus, 4) history of long-term drug use, 5) Auto-immune diseases. The healthy subjects were matched to cases with reference to ethnicity, age, gender, no history of acute or chronic diseases and absence of any infected viruses, or disorders. Before enrollment in the study written informed consent for research participation was signed from both pa $\neg$ tients and controls. The protocol of this study has the ethical approval no. 16472 as it was reviewed by the ethical committee of the National Research Center, Cairo, Egypt. This research was conducted in accordance with the principles of the Declaration of Helsinki.

\section{Methods}

Genomic DNA extraction: this was done from whole blood samples collected from 100 cases and 60 healthy controls by using Salting out method as described earlier (Omran and Fotouh et al., 2013). The quantity and quality of DNA were checked on a Nano Drop spectro-photometer and $0.8 \%(\mathrm{w} / \mathrm{v})$ agarose gel electrophoresis, respectively. The DNA was stored at $-80^{\circ} \mathrm{C}$ until further analysis.

\section{Genotyping}

Genomic variants of MTHFR polymorphisms (C677T and A1298C) were analyzed by (PCR-RFLP) assay. Amplification of MTHFR (C677T) was detected by forward primer 5'- TGA AGG AGA AGG TGT CTG CGG GA-3' and reverse primer 5'-AGG ACG GTG CGG TGA GAG TG -3'. While, Amplification of MTHFR (A1298C) was performed using forward primer 5'-AAGGAGGAGCTGCTGAAGATG-3'and reverse Primer 5'-CTTTGCCATGTCCACAGCATG-3'. PCR Reaction mix with final volume $(50 \mathrm{uL})$ contained 2 units Taq polymerase (finnzymes, Finland), $5 \mu$ Lof 10X PCR buffer (supplied with the enzyme), $0.2 \mathrm{mM}$ dNTPs( Promega, Madison WI, The USA), $1.5 \mathrm{mMMgCl}_{2}, 5 \mu \mathrm{M}$ from each primer, $200 \mathrm{ng}$ of DNA and DDW to $50 \mu \mathrm{L}$. Thermal cycling protocol comprised: initial denaturation at $95^{\circ} \mathrm{C}$ for 5 minutes, followed by 40 cycles each including $94^{\circ} \mathrm{C}$ for $30 \mathrm{sec}, 62^{\circ} \mathrm{C}$ for $30 \mathrm{sec}$, and $72^{\circ} \mathrm{C}$ for $30 \mathrm{sec}$, and a final extension step at $72^{\circ} \mathrm{C}$ for 10 minutes .Success $\neg$ fully amplified products were 198bp of MTHFR ( C677T) and 237 of MTHFR (A1298C) were digested with 10 units of restriction endonucleases: Hinfl enzyme for ( C677T) and MboII enzyme for (A1298C) (Promega, Madison, WI, USA ) and incubated at $37^{\circ} \mathrm{C}$ overnight (Frosst et al., 1995; Cicek et al., 2004). Restricted fragments were resolved on $3 \%$ agarose gel electrophore $\neg$ s in parallel with a DNA size marker (Amersham Pharma $\neg$ cia- Biotech). The presence of (TT) genotype of C677T was indicated by complete digestion (homozygous cut) of the $198 \mathrm{bp}$ PCR product using Hinfl enzyme into two fragments of (175 bp and $23 \mathrm{bp}$ ). While, (CC genotype) of A1289C was indicated by the complete digestion (homozygous cut) of the $237 \mathrm{bp} \mathrm{PCR} \mathrm{product} \mathrm{using} \mathrm{MboII} \mathrm{enzyme} \mathrm{into}$ the fragments of (182 bp and 28 and $27 \mathrm{bp}$ ). However, the presence of (CC genotype) of C677T and (AA genotype) of A1289C was indicated by absence of each of Hinfl and MboII sites respectively generated an indigestible sequence (No-cut) (Figure 1).

Sequencing Analysis DNA sequence was performed using reverse primer to the PCR products of (CC, CT and TT) genotypes of (C677T) and (AA, AC, CC) genotypes of (A1298C) to confirm the MTHFR polymorphisms of (C677T and A1298C) (Figure 2). The sequenced samples 
were analyzed in the $\mathrm{Au} \neg$ tomated Sequencer "ABI Prism 310 Genetic Analyzer". The sequences were aligned with the consensus sequences that were retrieved from Gene Bank using the program ClustalX implemented in the Bioedit package (Omran and Nabil et al., 2013).

Statistical analysis was performed using statistical software SPSS (Statistical Package for Social Science) statistical program version (20.0) and Microsoft Excel program version 2016. Quantitative data were statistically represented in terms minimum, maximum, mean, standard division (SD) and median. Qualitative data were statistically represented in terms number and percent. Comparison between difference groups in the present study was done using Independent samples T-Test for comparing two parametric groups and by using Chi-Square Test with Relative Risk and Odds ratio, and the analysis of association between each polymorphism and breast cancer risk was presented in odds ratios (OR) with corresponding $95 \%$. The allelic frequencies of each SNP were compared between cases and controls and the wide-type genotype was regarded as the reference group. Haplotype frequency distributions were deduced from genotype data and compared between cases and controls. The most common haplotype was selected as the reference. Odds ratios and $95 \%$ CI were calculated to estimate the degree of the association between haplotypes and the risk of breast cancer. A difference between groups was considered to be significant if $\mathrm{P}<0.05$ (Sole et al., 2006).

\section{Results}

Clinicopathological Data of Patients with Breast Cancer

Table 1, It shows all of the clinical and pathological parameters of BC patients enrolled in this study: age, family history, menopausal status, histological type, tumor size and stage, involvement of cancer in lymph node, metastases. It also shows hormone receptor status including: estrogen receptor (ER) and progesterone receptor (PR), human epidermal growth factor receptor 2 (HER2 neu). Most cases had mean age above 45 years $(63 \%)$ and were post-menopausal (60\%). Also, (66\%) of patients were sporadic as they did not have a family history of BC. Histopathologically, most of patients $(83 \%)$ had intermediate tumor grade (2). Moreover, a large proportion of them $(80 \%)$ had invasive ductal carcinoma (IDC) and (53\%) showed advanced stage tumor (III). Furthermore, most of these cases harbored a positive Her-2 neu (69\%), ER- negative (54\%) and PR- negative (58\%). However, some of them (37\%) and $(27 \%)$ had involvement of cancer in lymph nodes N1 and $\mathrm{N} 2$ respectively, while metastasis was confirmed in only $4 \%$ of cases.

Genotypes and alleles distribution of MTHFRC677T and MTHFRA1289C genes in patients with Breast Cancer and Controls

Table 2, shows a strong significant association of the SNPs of C/T genotypes of MTHFRC677T and the A/C genotypes of MTHFRA1289C with BC in four genetic models including dominant, recessive, codominant, and
Table 1. Clinico Pathological Data of Patients with Breast Cancer (BC).

\begin{tabular}{|c|c|}
\hline Parameters & Breast cancer patients $(n=100)(\%)$ \\
\hline \multicolumn{2}{|l|}{ Age (years) } \\
\hline$\leq 45$ & $37(37)$ \\
\hline$>45$ & $63(63)$ \\
\hline \multicolumn{2}{|l|}{ Family history } \\
\hline Familiar & $34(34)$ \\
\hline Sporadic & $66(66)$ \\
\hline \multicolumn{2}{|l|}{ Menopausal status } \\
\hline Postmenopausal & $60(60)$ \\
\hline premenopausal & $40(40)$ \\
\hline \multicolumn{2}{|l|}{ Pathology } \\
\hline IDC & $80(80)$ \\
\hline ILC & $20(20)$ \\
\hline \multicolumn{2}{|l|}{ Estrogen receptors } \\
\hline Positive & $46(46)$ \\
\hline Negative & $54(54)$ \\
\hline \multicolumn{2}{|c|}{ Progesterone receptors } \\
\hline Positive & $42(42)$ \\
\hline Negative & $58(58)$ \\
\hline \multicolumn{2}{|l|}{ HER 2 neu } \\
\hline Positive & $69(69)$ \\
\hline Negative & $31(31)$ \\
\hline \multicolumn{2}{|l|}{ Tumor size } \\
\hline $\mathrm{T} 1$ & $19(19)$ \\
\hline $\mathrm{T} 2$ & $39(39)$ \\
\hline T3 & $23(23)$ \\
\hline $\mathrm{T} 4$ & $19(19)$ \\
\hline \multicolumn{2}{|l|}{ Lymph nodes } \\
\hline No & $34(34)$ \\
\hline N1 & $37(37)$ \\
\hline $\mathrm{N} 2$ & $27(27)$ \\
\hline N3 & $2(2)$ \\
\hline \multicolumn{2}{|l|}{ Stage } \\
\hline I & $17(17)$ \\
\hline II & $26(26)$ \\
\hline III & $53(53)$ \\
\hline IV & $4(4)$ \\
\hline \multicolumn{2}{|l|}{ Grade } \\
\hline 2 & $83(83)$ \\
\hline 3 & $17(17)$ \\
\hline \multicolumn{2}{|l|}{ Metastasis } \\
\hline M0 & $96(96)$ \\
\hline M1 & $4(4)$ \\
\hline
\end{tabular}

IDC, Invasive ductal carcinoma; ILC, Invasive lobular carcinoma; HER2Neu, Human epidermal growth factor 2

overdominant models with highly significant $\mathrm{P}$ value $(\mathrm{P}=0.001)$. The percentage of CT and TT genotypes of $\mathrm{C} 677 \mathrm{~T}$ (55\% and $27 \%$ respectively) was much higher in affected patients versus $(20 \%$ and $0 \%)$ in control group. In the second study, it was demonstrated that the 
Table 2. MTHFR C677T and A1298C Genotypes \& Alleles Distribution in Breast Cancer Patients and Control

\begin{tabular}{|c|c|c|c|c|c|}
\hline Gene & Model & Genotype & Patients $(n=100)(\%)$ & Controls $(\mathrm{n}=60)(\%)$ & OR $(95 \% \mathrm{CI})$ \\
\hline \multirow[t]{11}{*}{ MTHFR C677T } & \multirow[t]{3}{*}{ Codominant } & $\mathrm{CC}$ & $18(18.0)$ & $40(66.7)$ & 1.00 (Reference) \\
\hline & & $\mathrm{CT}$ & $55(55.0)$ & $20(33.3)$ & $6.111(2.870-13.014)$ \\
\hline & & $\mathrm{TT}$ & $27(27.0)$ & $0(0.0)$ & $3.222(2.196-4.729)$ \\
\hline & \multirow[t]{2}{*}{ Dominant } & $\mathrm{CC}$ & $18(18.0)$ & $40(66.7)$ & 1.00 (Reference) \\
\hline & & CT-TT & $82(82.0)$ & $20(33.3)$ & $9.111(4.345-19.106)$ \\
\hline & \multirow[t]{2}{*}{ Recessive } & CC-CT & $73(73.0)$ & $60(100.0)$ & 1.00 (Reference) \\
\hline & & TT & $27(27.0)$ & $0(0.0)$ & $1.822(1.562-2.125)$ \\
\hline & \multirow[t]{2}{*}{ Overdominant } & CC-TT & $45(45.0)$ & $40(66.7)$ & 1.00 (Reference) \\
\hline & & $\mathrm{CT}$ & $55(55.0)$ & $20(33.3)$ & $2.444(1.256-4.757)$ \\
\hline & \multirow[t]{2}{*}{ Allele } & $\mathrm{C}$ & $91(45.5)$ & $100(83.3)$ & 1.00 (Reference) \\
\hline & & $\mathrm{T}$ & $109(54.5)$ & $20(16.7)$ & $(3.438-10.432) 5.989$ \\
\hline \multirow[t]{11}{*}{ MTHFR A1298C } & \multirow[t]{3}{*}{ Codominant } & AA & $11(11.0)$ & $32(53.3)$ & 1.00 (Reference) \\
\hline & & $\mathrm{AC}$ & $43(43.0)$ & $24(40.0)$ & $5.212(2.233-12.167)$ \\
\hline & & $\mathrm{CC}$ & $46(46.0)$ & $4(6.7)$ & $33.455(9.778-114.467)$ \\
\hline & \multirow[t]{2}{*}{ Dominant } & AA & $11(11.0)$ & $32(53.3)$ & 1.00 (Reference) \\
\hline & & $\mathrm{AC}-\mathrm{CC}$ & $89(89.0)$ & $28(46.7)$ & $9.247(4.130-20.703)$ \\
\hline & \multirow[t]{2}{*}{ Recessive } & $\mathrm{AA}-\mathrm{AC}$ & $54(54.0)$ & $56(93.3)$ & 1.00 (Reference) \\
\hline & & $\mathrm{CC}$ & $46(46.0)$ & $(6.7) 4$ & $11.926(4.018-35.398)$ \\
\hline & \multirow[t]{2}{*}{ Overdominant } & $\mathrm{AA}-\mathrm{CC}$ & $57(57.0)$ & $36(60.0)$ & 1.00 (Reference) \\
\hline & & $\mathrm{AC}$ & $43(43.0)$ & $24(40.0$ & $1.132(0.590-2.169)$ \\
\hline & \multirow[t]{2}{*}{ Allele } & A & $65(32.5)$ & $88(73.3)$ & 1.00 (Reference) \\
\hline & & $\mathrm{C}$ & $135(67.5)$ & $32(26.7)$ & $5.712(3.460-9.429)$ \\
\hline \multicolumn{6}{|c|}{ Haplotypes (CombinedGenotypes) (C677T/A1298C) } \\
\hline & & $\mathrm{CC} / \mathrm{AA}$ & $7(7)$ & $22(36.7)$ & 1.00 (Reference) \\
\hline & & $\mathrm{CC} / \mathrm{AC}$ & $7(7)$ & $14(23.3)$ & $1.571(0.453-5.450)$ \\
\hline & & $\mathrm{C} / \mathrm{CC}$ & $4(4)$ & $4(6.7)$ & $3.143(0.618-15.978)$ \\
\hline & & CT/AA & $4(4)$ & $10(16.7)$ & $1.257(0.298-5.296)$ \\
\hline & & $\mathrm{CT} / \mathrm{AC}$ & $25(25)$ & $10(16.7)$ & $7.857(2.556-24.154)$ \\
\hline & & $\mathrm{CT} / \mathrm{CC}$ & $26(26)$ & $0(0)$ & $4.143(2.173-7.898)$ \\
\hline & & TT/AA & $0(0)$ & $0(0)$ & ---------- \\
\hline & & $\mathrm{TT} / \mathrm{AC}$ & $11(11)$ & $0(0)$ & $4.143(2.173-7.898)$ \\
\hline & & $\mathrm{TT} / \mathrm{TT}$ & $16(16)$ & $0(0)$ & $4.143(2.173-7.898)$ \\
\hline
\end{tabular}

percentage of CC $(46 \%)$ of MTHFRA1289C was much higher in patients versus controls $(6.7 \%)$ with a highly significant $\mathrm{P}$ value $(\mathrm{P}=0.001)$. Moreover, it is observed that the patients with breast cancer had a significant association with the $\mathrm{T}$ allele of MTHFRC677T and with the $\mathrm{C}$ allele of MTHFRA1289C $(\mathrm{P}=0.001)$. Furthermore, it was found that the haplotype $\mathrm{CT} / \mathrm{AC}$ followed by $\mathrm{CT} /$ $\mathrm{CC}, \mathrm{TT} / \mathrm{AC}$ and $\mathrm{TT} / \mathrm{CC}$ was associated with elevated risk of $\mathrm{BC}(\mathrm{P}=0.001)$.

\section{Statistical Analysis}

Table 3, clarifies the data that was analyzed by the Univariate statistical analysis that involved only one variable to enlighten patterns within the data. In two separate studies this analysis revealed strong significant correlation of the SNPs of (TC+TT) of MTHFR C677T in one study and that of $(\mathrm{AC}+\mathrm{CC})$ of MTHFR A1298C in the other study versus each of the $\mathrm{BC}$ clinicopathological data including: dual negativity of ER and PR, high HER2neu expression, involvement of cancer in lymph nodes and advanced tumor stage (III-IV) and bigger size (T2-T3) giving highly significant $\mathrm{P}$ values (0.001).

Table 4, demonstrates the Multivariate statistical analysis by using a logistic regression that was done between three or more variables of the data in two separate studies evaluating the association of the SNPs of each of MTHFR C677T and those of MTHFR A1298C versus the $\mathrm{BC}$ clinicopathological data. This analysis discovered very highly significant $\mathrm{P}$ values (0.001) of (CC vs CTTT) of MTHFR C677T within big tumor size, advanced tumor stage, and involvement of cancer in lymph nodes, overexpression of HER2neu and dual negativity of ER and PR hormones. Also, there was a powerful significant correlation between (AA vs AC-CC) of MTHFR A1298C and HER2neu expression and tumor stage.

Table 5, demonstrates that the most frequent haplotype 


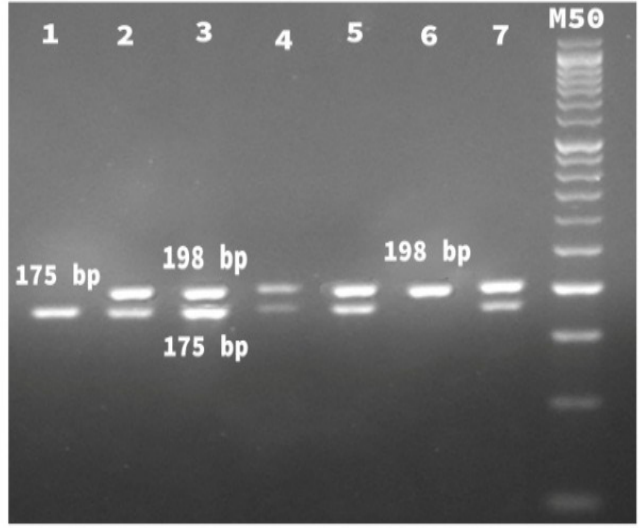

A

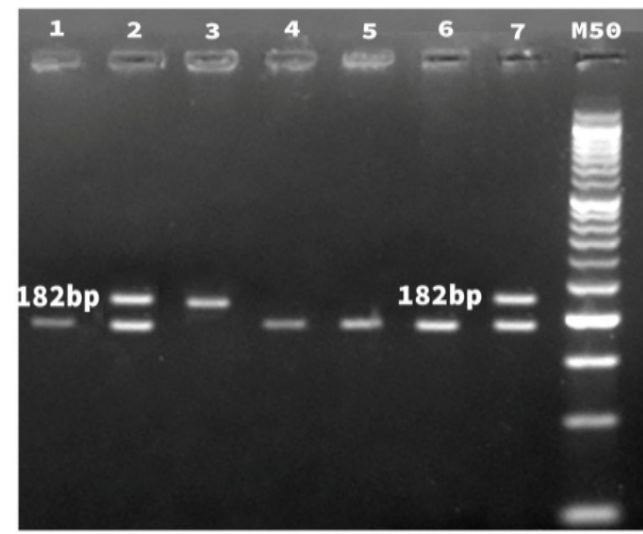

B

Figure 1. Agarose Gel Electrophoresis of Digested MTHFR C677T \& MTHFR A1289C Amplicons (A) MTHFR C677T: Lane 1represents homozygous cut (TT) (175bp), Lanes 2,3,4,5,7 represent heterozygous cut (CT) (198bp \& 175 bp), Lane 6 shows no cut (CC) (198bp), (M) represents 50bp molecular weight marker. (B) MTHFR A1289C: Lanes 1,4,5,6 show homozygous cut (CC) (182bp), Lanes 2,7 show heterozygous cut (AC) (237 bp and 182 bp), Lane 3 represents no cut (AA) .(M) represents $50 \mathrm{bp}$ molecular weight marker.

of the two loci of MTHFR (rs1801133-rs1801131) was TC which was strongly associated with the aggressive clinical features of each of big tumor size, advanced stage, involvement of cancer in lymph nodes, overexpression of HER2neu and dual negativity of both ER and PR hormones giving highly significant $\mathrm{P}$ values $(0.001)$

\section{Discussion}

Breast cancer is a complex and heterogeneous disease and the main cause of cancer death in females (Castigilia et al., 2019). Various environmental and genetic factors, with mutations in more than one polymorphism ( $S N P S$ ) play interrelated roles in the pathophysiology of cancer, disease

Table 3. Univariate Analysis of MTHFR C677T and MTHFR

\begin{tabular}{|c|c|c|c|c|c|c|}
\hline Parameters & $\begin{array}{c}\text { MTHFR C677T } \\
\text { CT-TT } \\
\text { n }(\%)\end{array}$ & $\begin{array}{c}\text { MTHFR C677T } \\
\text { CC } \\
\text { n (\%) }\end{array}$ & OR $(95 \% \mathrm{CI})$ & $\begin{array}{c}\text { MTHFR A1298C } \\
\text { AC-CC } \\
\text { n }(\%)\end{array}$ & $\begin{array}{c}\text { MTHFR A1298C } \\
\text { AA } \\
\text { n (\%) }\end{array}$ & OR $(95 \% \mathrm{CI})$ \\
\hline \multicolumn{7}{|l|}{ Age } \\
\hline $45 \geq$ & $(34.1) 28$ & (50) 9 & (Reference) 1.00 & $(37.1) 33$ & (36.4) 4 & (Reference) 1.00 \\
\hline $45<$ & (65.9) 54 & (50) 9 & $1.929(0.688-5.405)$ & $(62.9) 56$ & (63.6) 7 & $0.970(0.264-3.564)$ \\
\hline \multicolumn{7}{|l|}{$\mathrm{ER} / \mathrm{PR}$} \\
\hline both -ve & (54.9) 45 & (16.7) 3 & (Reference) 1.00 & $(51.7) 46$ & $2(18.2)$ & (Reference) 1.00 \\
\hline both +ve & $21(25.6)$ & $15(83.3)$ & $0.093(0.024-0.358)$ & $(31.5) 28$ & $8(72.7)$ & $0.152(0.030-0.768)$ \\
\hline \multicolumn{7}{|l|}{ HER2neu } \\
\hline ve- & $16(19.5)$ & $15(83.3)$ & (Reference) 1.00 & $(25.8) 23$ & $8(72.7)$ & (Reference) 1.00 \\
\hline ve+ & $66(80.5)$ & $3(16.7)$ & $20.625(5.322-79.924)$ & $(74.2) 66$ & $3(27.3)$ & $7.652(1.870-31.318)$ \\
\hline \multicolumn{7}{|l|}{ Tumor size } \\
\hline $\mathrm{T} 1$ & $(8.5) 7$ & (66.7) 12 & (Reference) 1.00 & (12.4) 11 & $8(72.7)$ & (Reference) 1.00 \\
\hline $\mathrm{T} 2-\mathrm{T} 4$ & $(91.5) 75$ & $(33.3) 6$ & $21.429(6.145-74.729)$ & (87.6) 78 & $3(27.3)$ & $18.909(4.350-82.191)$ \\
\hline \multicolumn{7}{|c|}{ Lymph nodes } \\
\hline No & (23.2) 19 & $15(83.3)$ & 1.00 (Reference) & (30.3) 27 & $(63.6) 7$ & 1.00 (Reference) \\
\hline N1-N3 & $63(76.8)$ & $3(16.7)$ & $16.579(4.334-63.414)$ & $(69.7) 62$ & $4(36.4)$ & $4.019(1.085-14.878)$ \\
\hline \multicolumn{7}{|l|}{ Metastasis } \\
\hline M0 & $78(95.1)$ & $18(100)$ & 1.00 (Reference) & $(95.5) 85$ & $11(100)$ & 1.00 (Reference) \\
\hline M1 & $4(4.9)$ & (0) 0 & $1.231(1.118-1.355)$ & $(4.5) 4$ & (0) 0 & $1.129(1.051-1.214)$ \\
\hline \multicolumn{7}{|l|}{ Stage } \\
\hline I-II & $28(34.1)$ & $15(83.3)$ & 1.00 (Reference) & (39.3) 35 & $8(72.7)$ & 1.00 (Reference) \\
\hline III-IV & $54(65.9)$ & $3(16.7)$ & $9.643(2.573-36.132)$ & $(60.7) 54$ & $3(27.35)$ & $4.114(1.021-16.574)$ \\
\hline \multicolumn{7}{|l|}{ Grade } \\
\hline 2 & $65(79.3)$ & $18(100)$ & 1.00 (Reference) & (80.9) 72 & $11(100)$ & 1.00 (Reference) \\
\hline 3 & $17(20.7)$ & (0) 0 & $1.277(1.140-1.430)$ & (19.1) 17 & (0) 0 & $1.153(1.060-1.254)$ \\
\hline
\end{tabular}

HER2Neu, Human epidermal growth factor 2; ER, estrogen receptor; PR, progesterone receptor; OR, Odds ratio; CI, confidence interval 
Table 4. Multivariate Analysis of MTHFR C677T \& MTHFR A1298C

\begin{tabular}{lcccccc}
\hline Parameters & \multicolumn{2}{c}{ MTHFR C677T(CC vs CT-TT) } & \multicolumn{2}{c}{ (MTHFR A1298C (AA vs AC-CC } \\
& OR & \multicolumn{2}{c}{ 95\% C.I. } & OR & \multicolumn{2}{c}{ 95\% C.I. } \\
& & Lower limit & Upper limit & & Lower limit & Upper limit \\
\hline HER 2 Neuo ( -ve, +ve) & 20.625 & 5.322 & 79.924 & 7.652 & 1.870 & 31.318 \\
Tumor Size (T1, T2-T4) & 21.429 & 6.145 & 74.729 & 18.909 & 4.350 & 82.191 \\
LYMPH Nodes (N0, N1-N3) & 16.579 & 4.334 & 63.414 & 4.019 & 1.085 & 14.878 \\
(M0,M1)Metastasis & $3.73 \mathrm{E}+08$ & 0 &. & $2.09 \mathrm{E}+08$ & 0.000 &. \\
Stage (I-II, III-IV) & 9.643 & 2.573 & 36.132 & 4.114 & 1.021 & 16.574 \\
Grade (2, 3) & $4.47 \mathrm{E}+08$ & 0 &. & $2.47 \mathrm{E}+08$ & 0.000 &. \\
ER /PR (Both -ve, Both +ve) & 0.806 & 0.713 & 0.911 & 0.843 & 0.727 & 0.976 \\
\hline
\end{tabular}

HER2Neu, Human epidermal growth factor 2; ER, estrogen receptor; PR, progesterone receptor; OR, Odds ratio; CI, confidence interval

progression, and spontaneous or drug-induced viral clearance (Omran and Ibrahim et al., 2013; Moghaddam et al., 2018; Bagheri-Hossein et al., 2020). Therefore, the present study mainly aims to investigate the role of two functional and signalized SNPs in the MTHFR gene, C677T (rs 1801133) and A1298C (rs 1801131) as risk factors for breast cancer patients. These mutant alleles of MTFHR polymorphic variants have been associated with the decreased Folate enzyme activity, as its metabolism works as a Cycle; interact with each other through their substrates, causing increased levels of plasma homocysteine (Rozen, 1997). This decreases the efficiency of purines and pyrimidine synthesis as well as DNA regulation and integrity that may contribute to malignant transformation (Duthie, 1999; Choi and Mason,
2000). Thus, this study was conducted to highlight the role of these mutant alleles that contribute in increasing cancer risk in Egyptian females' patients by developing more aggressive phenotypes that increase tumor size, stage and spread into the nearby lymph nodes and others.

In the analysis of the demographic and clinical features of BC patients, our data showed that the risk of $\mathrm{BC}$ increased by the increasing age as $63 \%$ of patients are over 45 years old. These results are in agreement with (El- Bolkainy et al., 2005; Extermann et al., 2012) who reported that by aging, DNA repair becomes less efficient, allowing more mutations, chromosomal breaks and translocations. This leads to the inactivation of tumor suppressor genes, and hinder the function of DNA repair genes. Furthermore, it was debated that family history is

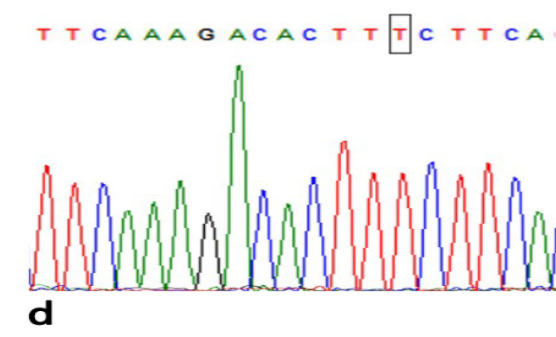

T T CAAAGACACTTGCTTCA

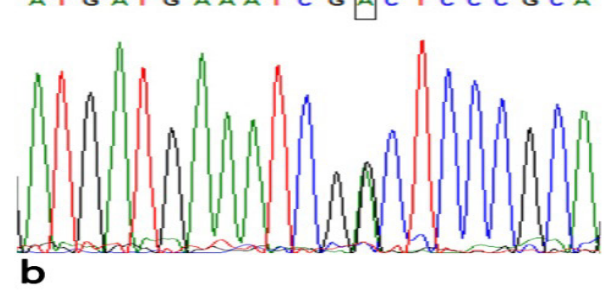

ATGATGAAATCGACTCCCGCA

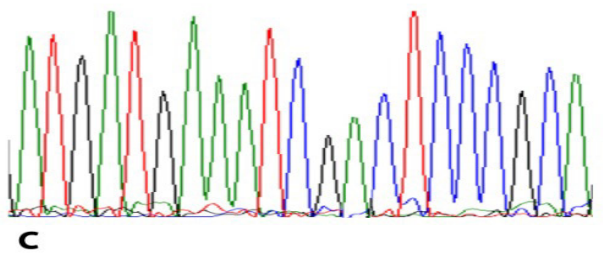

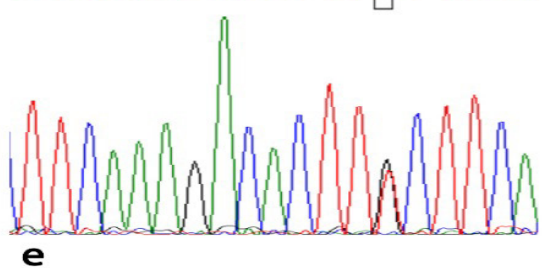

TTCAAAGACACTTG

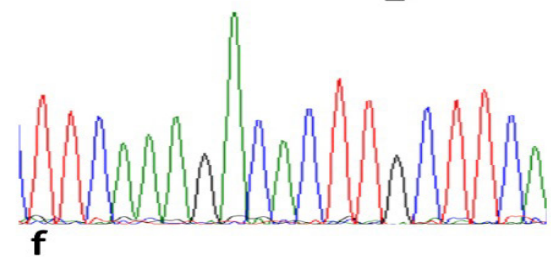

Figure 2. Sequencing Analysis Using Reverse Primer of MTHFR C677T \& A1298C Genotypes. MTHFR C677T: (a) wild type CC genotype, (b) heterozygous CT genotype, (c) homozygous mutant TT genotype. MTHFR A1289C: (d) wild type AA genotype, (e) heterozygous AC genotype, (f) homozygous mutant CC genotype. 
Table 5. Association of MTHFR Haplotypes with Clinical Characteristics of Breast Cancer PatientS

\begin{tabular}{|c|c|c|c|}
\hline \multirow{2}{*}{$\begin{array}{l}\text { Haplotype } \\
\text { (C677T -A1298C) }\end{array}$} & \multicolumn{2}{|c|}{ n (\%) } & \multirow[t]{2}{*}{ OR $(95 \%$ CI $)$} \\
\hline & $45<$ & $45=>$ & \\
\hline C-A & $56(32.2)$ & $72(49.3)$ & 1.00 (Reference) \\
\hline $\mathrm{C}-\mathrm{C}$ & $39(22.4)$ & $24(16.4)$ & $2.089(1.127-3.872)$ \\
\hline T-A & $17(9.8)$ & $8(5.5)$ & $2.732(1.100-6.788)$ \\
\hline T-C & $62(35.6)$ & $42(28.8)$ & $1.898(1.123-3.208)$ \\
\hline \multicolumn{4}{|c|}{ PR } \\
\hline & ve+ + & ve- & \\
\hline C-A & $32(38.1)$ & $18(15.5)$ & 1.00 (Reference) \\
\hline $\mathrm{C}-\mathrm{C}$ & $21(25.0)$ & $20(17.2)$ & $0.591(0.255-1.370)$ \\
\hline T-A & $5(6.0)$ & $10(8.6)$ & $0.281(0.083-0.952)$ \\
\hline $\mathrm{T}-\mathrm{C}$ & $26(31.0)$ & $68(58.6)$ & $0.215(0.103-0.448)$ \\
\hline \multicolumn{4}{|c|}{ ER } \\
\hline & $\mathrm{ve}+$ & ve- & \\
\hline C-A & $34(37.0)$ & $16(14.8)$ & 1.00 (Reference) \\
\hline $\mathrm{C}-\mathrm{C}$ & $22(23.9)$ & $19(17.6)$ & $0.545(0.232-1.280)$ \\
\hline T-A & $7(7.6)$ & $8(7.4)$ & $0.412(0.127-1.334)$ \\
\hline T-C & $29(31.5)$ & $65(60.2)$ & $0.210(0.100-0.439)$ \\
\hline \multicolumn{4}{|c|}{ HER 2 Neuo } \\
\hline & ve+ & ve- & \\
\hline C-A & $23(16.7)$ & $27(43.5)$ & 1.00 (Reference) \\
\hline $\mathrm{C}-\mathrm{C}$ & $25(18.1)$ & $16(25.8)$ & $1.834(0.793-4.242)$ \\
\hline T-A & $9(6.5)$ & $6(9.7)$ & $1.761(0.545-5.692)$ \\
\hline $\mathrm{T}-\mathrm{C}$ & $81(58.7)$ & $13(21.0)$ & $7.314(3.262-16.403)$ \\
\hline \multicolumn{4}{|c|}{ Tumor Size } \\
\hline & $\mathrm{T} 2-\mathrm{T} 4$ & $\mathrm{~T} 1$ & \\
\hline C-A & $32(19.8)$ & $18(47.4)$ & 1.00 (Reference) \\
\hline $\mathrm{C}-\mathrm{C}$ & $29(17.9)$ & $12(31.6)$ & $1.359(0.560-3.299)$ \\
\hline T-A & $12(7.4)$ & $3(7.9)$ & $2.250(0.560-9.040)$ \\
\hline T-C & $89(54.9)$ & $5(13.2)$ & $10.012(3.434-29.190)$ \\
\hline \multicolumn{4}{|c|}{ Lymph Nodes } \\
\hline & N1 - N3 & No & \\
\hline C-A & $25(18.9)$ & $25(36.8)$ & 1.00 (Reference) \\
\hline $\mathrm{C}-\mathrm{C}$ & $20(15.2)$ & $21(30.9)$ & $0.952(0.417-2.175)$ \\
\hline T-A & $10(7.6)$ & $5(7.4)$ & $2.000(0.597-6.695)$ \\
\hline T-C & $77(58.3)$ & $17(25.0)$ & $4.529(2.111-9.721)$ \\
\hline \multicolumn{4}{|c|}{ Stage } \\
\hline & III - IV & I - II & \\
\hline C-A & $17(14.9)$ & $33(38.4)$ & 1.00 (Reference) \\
\hline $\mathrm{C}-\mathrm{C}$ & $19(16.7)$ & $22(25.6)$ & $1.676(0.718-3.915)$ \\
\hline T-A & $10(8.8)$ & $5(5.8)$ & $3.882(1.143-13.185)$ \\
\hline $\mathrm{T}-\mathrm{C}$ & $68(59.6)$ & $26(30.2)$ & $5.077(2.424-10.634)$ \\
\hline \multicolumn{4}{|c|}{ Grade } \\
\hline & 3 & 2 & \\
\hline C-A & $2(5.9)$ & $48(28.9)$ & 1.00 (Reference) \\
\hline $\mathrm{C}-\mathrm{C}$ & $9(26.5)$ & $32(19.3)$ & $6.750(1.368-33.304)$ \\
\hline T-A & $2(5.9)$ & $13(7.8)$ & $3.692(0.474-28.783)$ \\
\hline T-C & $21(61.8)$ & $73(44.0)$ & $6.904(1.548-30.801)$ \\
\hline \multicolumn{4}{|c|}{ Metastasis } \\
\hline & M1 & M0 & \\
\hline C-A & $0(0.0)$ & $50(26.0)$ & 1.00 (Reference) \\
\hline $\mathrm{C}-\mathrm{C}$ & $2(25.0)$ & $39(20.3)$ & $0.951(0.888-1.019)$ \\
\hline T-A & $1(12.5)$ & $14(7.3)$ & $0.933(0.815-1.069)$ \\
\hline $\mathrm{T}-\mathrm{C}$ & $5(62.5)$ & $89(46.4)$ & $0.947(0.903-0.993)$ \\
\hline
\end{tabular}

HER2Neu, Human epidermal growth factor 2; ER, estrogen receptor; $\mathrm{PR}$, progesterone receptor; OR, Odds ratio; $\mathrm{CI}$, confidence interval
Correlation of MTHFR SNPs with BC in Egyptian Females

extremely a major influence associated with increased risk of $\mathrm{BC}$. The inherited susceptibility of $\mathrm{BC}$ is partially attributed to the aberrant expression of DNA damage with mutations of related genes such as BRCA1 and BRCA2 (Brewer et al., 2017; Diotaiuti et al., 2020). On the other side, our findings showed that $66 \%$ of patients are sporadic and that is in accordance to the work of (Shaker and Senousy, 2019) who also found no association of BC with family history. Also, in the present study, it was revealed that $60 \%$ of $\mathrm{BC}$ cases were postmenopausal which is in accordance with (Kuller, 1995; Said et al., 2012; Floris et al., 2020). They explained that fat cells in patients' breasts tend to produce greater amounts of aromatase enzyme which promote estrogen production that plays a role in both the development and growth of breast cancer.

It was stated that the single nucleotide polymorphisms $(S N P S)$ are the most common form of genetic variation with more than nine million reported in public databases, causing alterations in protein structure, function and can be useful as physical markers for progression of the disease or drug response (Ibrahim et al., 2016; Alkasaby et al., 2020). Further research in molecular aspects of cancers has led to pay closer attention to study polymorphisms of genes involved in tumor genesis (Hosseini, 2013; Youssef et al., 2013; Liu et al, 2020). Findings from this present study identified that MTHFR C677T and A1298C polymorphisms are associated with BC. Strong correlations between Egyptian BC patients and controls are found in four genetic models including codominant, dominant, recessive and overdominant models with mostly highly significant $\mathrm{P}$ value $(\mathrm{P}=0.001)$ between MTHFR C677T genotypes $(\mathrm{C} / \mathrm{T}+\mathrm{T} / \mathrm{T})$ with $55 \%$ in patients vs. $33.3 \%$ in controls. Combined genotypes of MTHFR A1289C $(\mathrm{AC}+\mathrm{CC})$ percentage was much higher in patients $(89 \%)$ than in controls $(46.7 \%)$ with high significant difference $(\mathrm{p}=0.001)$. In agreement to that, it is reported that mutation of MTHFR from $677 \mathrm{C}$ to T and A1298 to $\mathrm{C}$ reduces the enzyme activity that leads to decreasing the yield of methyl donor SAM which eventually affects the methylation of DNA causing hypomethylation and consecutive activation of carcinogenic oncogenes (Weisberg et al., 1998; Liu et al., 2012; Nie et al., 2020).

Furthermore, in this study, the frequency of $\mathrm{T}$ allele of MTHFR C677T in patients was $54.5 \%$ vs. $16.7 \%$ in controls with highly significant value $(\mathrm{P}=0.001)$, indicating that the risk of breast cancer increases by 5.98 times in individual carrying the $\mathrm{T}$ allele. These results are supported by previous studies conducted on different populations as Indian and Moroccan suggesting that this polymorphism could be a therapeutic target for breast cancer (Waseem et al., 2016; Hardi et al., 2018; Rahimi et al., 2019). On the other hand, some previous case-control studies of: Mexican, north Indian, Turkish and Chinese population did not report any relation (Mir et al., 2008; Ramos-Silivia et al., 2015; Kaya et al., 2016; Song et al., 2016). The reason for this discrepancy may be due to ethnic differences, different life style and gene-environmental interaction.

Additionally, our results revealed that $\mathrm{C}$ allele of MTHFR A1289C is highly distributed among BC patients than controls $(67.5 \%$ vs. $26.7 \%)$ giving a very 
high significant value $(\mathrm{P}=0.001)$. These results are supported by previous researches (Hosseini et al., 2011; Liu et al., 2016). Studies conducted on Turkish and Italian population demonstrated that the risk of breast cancer increase due to the presence of $\mathrm{C}$ allele as well as it is attributed to decreasing the enzyme activity by $15 \%$ and $30 \%$ for heterozygous (AC) and homozygous (CC) carriers respectively, as a result of change of C-terminal regulatory domain of the protein that is linked with carcinogenesis (Weisberg et al., 1998; Ergul et al., 2003; Pepe et al., 2006). However, other findings and case-control studies did not reveal any correlations (Jiao and Li, 2013; Rai et al., 2014; Awwad et al., 2015; Nie et al., 2020).

Furthermore, the interaction between genetic polymorphisms at the two loci was judged by evaluating the combined genotypes' effects (haplotype analysis). The genotypes of adjacent SNPs are in linkage disequilibrium and are frequently highly correlated, resulting in the major determining factors of disease predisposition compared to the single polymorphisms (Zintzaras and Lau, 2008). Thus, we analyzed the haplotype frequencies of the two MTHFR SNPs, 677C $>$ T, and 1298A $>C$ for BC cases comparing them with their aggressive clinical features. Our results revealed that the haplotype CT/AC was associated with elevated risk of $\mathrm{BC}(\mathrm{OR}=7.857,95 \% \mathrm{CI}$ $2.556-24.154, \mathrm{P}=0.001)$ followed by $\mathrm{CT} / \mathrm{CC}, \mathrm{TT} / \mathrm{AC}$ and TT/CC haplotypes $(\mathrm{OR}=4.143,95 \%$ CI 2.173 - 7.898, $\mathrm{P}=0.001)$. This indicates that the presence of the mutant haplotype generated less active thermo labile enzymes leading to global hypomethylation, increasing the risk of chromosomal breaks and consequently more aggressive features of breast carcinogenesis. These findings are in agreement with studies done by (Gao et al., 2009; Zhong et al., 2014). On the contrary, other studies among women from different populations reported no associations (Chou et al., 2006; Floris et al., 2020). Meanwhile, similar studies showed inconclusive results as, the $\mathrm{C}-\mathrm{C}$ haplotype was protective in East Asian and German populations (Justenhoven et al., 2005; Huang et al., 2011), while the C-A was protective among the South-Eastern European women (Papandreou, 2012). The T-C ,T-A haplotype in Jordanian and Caucasians populations were more susceptible to develop BC (Zhong et al., 2014; Awwad et al., 2015).

In this study, we performed further analysis of Univariate, Multivariate and Haplotype to investigate the relationship between the clinicopathological parameters and the distributions of SNPS of MTHFR C677T and A1289C genotypes in BC Egyptian patients. Our promising results of associations are represented by the significant correlations of (CT+TT) of MTHFR C677T and $(\mathrm{AC}+\mathrm{CC})$ of MTHFR A1289C polymorphisms by developing more aggressive clinical features. Our findings of haplotype analysis among Egyptian females also clarified that the most frequent haplotype of the two loci of MTHFR (rs1801133-rs1801131) is TC which was significantly associated with dual negativity of both ER and PR hormones, overexpression of HER2neu, lymph node metastasis and tumor size. These findings are evidenced by earlier reports (Rezende et al., 2017; Castigilia et al., 2019). However, there was no correlation of our data with age or disease onset. Other studies on Moroccan and Indian cases reported no statistical significant association with clinicopathological characteristics (Waseem et al., 2016; Hardi et al., 2018; Karimian et al., 2020). Moreover, all our data were confirmed in multivariate analysis to improve the validity of the results and to identify the independent association between different genotypes of the MTHFR C677T(rs1801133) and MTHFR A1289C rs1801131 and $\mathrm{BC}$. The results demonstrated that both polymorphisms are correlated with $\mathrm{BC}$ and it can be seen that there is a tendency towards the association between aggressiveness of tumor type and (ER-/PR-), over expression of HER2 neu, tumor size and stage with the mutant allele variants of MTHFR rs1801133 TT and MTHFR rs1801131 CC giving very highly significant values.

To sum up, the current study revealed clear evidence of the strong significant association of the genetic polymorphisms mutations of MTHFR at C677T and $A 1289 C$ with the increasing risk of BC among Egyptian females, confirmed by the Univariate, Multivariate and Haplotype analysis. Moreover, this is an early study demonstrating the correlations between MTHFR gene polymorphisms and the pathological and clinical features. This helps in providing a molecular detection by using these polymorphisms as predictive and prognostic markers for the development of breast cancer disease.

\section{Acknowledgements}

The authors would like to thank the medical staff at the Department of clinical and chemical pathology, National Cancer Institute, and the technical staff at Microbial Biotechnology Department, National Research Center. This study was funded with the support of Academy of Scientific Research through National Research Centre. The protocol of this study has the ethical approval no. 16472 by the ethical committee of the National Research Center, Cairo, Egypt.

\section{Authors' Contribution}

Omran M., established the molecular experiments, wrote and the manuscript and revised the statistical analysis and the manuscript; Fotouh B, performed most mo $\neg$ lecular experiments, shared in revising the statistical analysis and the manuscript; Shosha W., shared in revising the manuscript; Ismail A., shared in the medical and clinical Section. Ibrahim N. shared in some of the experiments. Ramadan S. shared in some of the experiments and revising the manuscript. There was no conflict of interest.

\section{References}

Alkasaby MK, Abd El-Fattah AI, Ibrahim IH, Abd El-Samie HS (2020). Polymorphism of XRCC3 in Egyptian breast cancer patients. Pharmgenomics Pers Med, 13, 273-82.

Awwad N, Yousef AM, Abuhaliema A, Abdalla I, Yousef M (2015). Relationship between genetic polymorphisms in MTHFR (C677T, A1298C and their Haplotypes) and the incidence of breast cancer among Jordanian females-casecontrol study. Asian Pac J Cancer Prev, 16, 5007-11.

Bagheri-Hosseinabadi Z, Imani DH, Yousefi H, Abbasifard M 
(2020). MTHFR gene polymorphisms and susceptibility to rheumatoid arthritis: a meta-analysis based on 16 studies. Clin Rheumatol, 39, 2267-79.

Brewer HR, Jones ME, Schoemaker MJ, Ashworth A, Swerdlow AJ (2017). Family history and risk of breast cancer: an analysis accounting for family structure. Breast Cancer Res Treat, 165, 193-200.

Carvalho Barbosa RD, Menezes DC, Freire TF, et al (2012). Associations of polymorphisms of folate cycle enzymes and risk of breast cancer in a Brazilian population are age dependent. Mol Biol Rep, 39, 4899-907.

Castiglia P, Sanna V, Azara A, et al (2019). Methylenetetrahydrofolate reductase (MTHFR) C677T and A1298C polymorphisms in breast cancer a Sardinian preliminary case-control study. Int J Med Sci, 16, 1089-95.

Choi SW, Mason JB (2000). Folate and carcinogenesis: an integrated scheme. J Nutr, 130, 129-32.

Chou YC, Wu MH, Yu JC, et al (2006).Genetic polymorphisms of the methylenetetrahydrofolate reductase gene, plasma folate levels, and breast cancer susceptibility: A case-control study in Taiwan. Carcinogenesis, 27, 2295-300.

Cicek MS, Nock NL, Li L, et al (2004).Relationship between methylenetetrahydrofolate reductase C677T and A1298C genotypes and haplotypes and prostate cancer risk and aggressiveness. Cancer Epidemiol Biomarkers Prev, 13, 1331-36.

Crider KS, Yang TP, Berry RJ, Bailey LB (2012). Folate and DNA methylation: a review of molecular mechanisms and the evidence for folate's role. Adv Nutr, 3, 21-38.

Diotaiuti S, De Summa S, Altieri R, et al (2020).Biomarker phenotyping drives clinical management in axillary sentinel node: A retrospective study on women with primary breast cancer in 2002. Oncol Lett, 20, 2469-76.

Donepudi M, Kondapalli K, Amos S, Venkanteshan P (2014). Breast cancer statistics and markers. J Cancer Res Ther, 10, 506-11.

Duthie SJ (1999). Folic acid deficiency and cancer: mechanisms of DNA instability. Br Med Bull, 55, 578-92.

El-Bolkainy MN, Nouh AM (2005).Topographic pathology of cancer, third edition. NCI, CairoUniversity.

Ergul E, Sazci A, Utkan Z, Canturk NZ (2003). Polymorphisms in the MTHFR gene are associated with breast cancer Tumour Biol, 24, 286-90.

Extermann M, Movsas B (2012).Introduction: Cancer, Ageing and Comorbidities. Semin Radiat Oncol, 22, 263-4.

Floris M, Sanna D, Castiglia P, et al (2020). MTHFR, XRCC1 and OGG1 genetic polymorphisms in breast cancer .a casecontrol study in a population from North Sardinia. BMC Cancer, 20, 1-15.

Frosst P, Blom HJ, Milos R, et al (1995).A candidate genetic risk factor for vascular disease: a common mutation in methylenetetrahydrofolate reductase. Nat Genet, 10, 111-3.

Gao CM, Kazuo T, Tang JH, et al (2009). MTHFR polymorphisms, dietary folate intake and risks to breast cancer. Zhonghua yu fang yi xue za zhi [Chinese journal of preventive medicine], 43, 576-80.

Gorringe KL, Fox SB (2017).Ductal carcinoma in situ biology, biomarkers, and diagnosis. Front Oncol, 7, 248.

Hajiesmaeil M, Tafvizi F, Sarmadi S (2016). The effect of methylenetetrahydrofolate to human papilloma virus infection and cervical cancer. Infect Genet Evol, 46, 1-6.

Hardi H, Melki R, Boughaleb Z, et al (2018).Significant association between ERCC2 and MTHR polymorphisms and breast cancer susceptibility in Moroccan population: genotype and haplotype analysis in a case-control study. BMC Cancer, 18, 292.

Hosseini M (2013). Role of polymorphism of

\section{Correlation of MTHFR SNPs with BC in Egyptian Females}

methyltetrahydrofolate-homocysteine methyltransferase (MTR) A2756G and breast cancer risk. Pol J Pathol, 64, 191-5.

Hosseini M, Houshmand M, Ebrahimi A (2016).MTHFR polymer morphisms and breast cancer risk. Arch Med Sci, 7, 134-7.

Huang T, Tucker KL, Lee YC, et al (2011). Methylenetetrahydrofolate reductase variants associated with hypertension and cardiovascular disease interact with dietary polyunsaturated fatty acids to modulate plasma homocysteine in Puerto Rican adults. J Nutr, 141, 654-9.

Ibrahim AS, Khaled HM, Mikhail NN, Baraka H, Kamel H (2014). Cancer incidence in Egypt: results of the National Population-Based Cancer RegistryProgram. J Cancer Epidemiol, 2014, 1-18.

Ibrahim MK, Salama H, Abd El Rahman M, et al (2016). Three gene signature for predicting the development of hepatocellular carcinoma in chronically infected hepatitis $\mathrm{C}$ virus patients. J Interferon Cytokine Res, 36, 698-705.

Jiao Z, Li D (2013). Lack of association between MHTFR Glu429Ala polymorphism and breast cancer susceptibility: a systematic review and meta-analysis of 29 research studies. Tumor Biol, 34, 1225-33.

Justenhoven C, Hamann U, Pierl CB, et al (2005). One carbon metabolism and breast cancer risk: no association of MTHFR, MTR, and TYMS polymorphisms in the GENICA study from Germany. Cancer Epidemiol Prev Biomarkers, 14, 3015.

Karimian M, Rezazadeh N, Khamehchian T (2020). Association analysis of methylenetetrahydrofolate reductase common gene polymorphisms with breast cancer risk in an Iranian population: A Case-Control Study and a Stratified Analysis. Asian Pac J Cancer Prev, 21, 2709-14.

Kaya EF, Karakus N, Ulusoy AN, Özaslan C, Kara N (2016). Association of the MTHFR gene (C677T) polymorphism with breast cancer in a Turkish population. Oncol Res Treat, 39, 534-8.

Kekeeva TV, Zhevlova AI, Podistov YI, et al (2006). Aberrant methylation of tumor suppressor genes and allelic imbalance in cervical intraepithelial neoplasia. Mol Biol, 40, 194-99.

Kuller LH (1995). The etiology of breast cancer - from epidemiology to prevention. Public Health Rev, 23, 157-213.

Liu C, Zhao J, Lu W, et al (2020). Individualized genetic network analysis reveals new therapeutic vulnerabilities in 6,700 cancer genomes. PLoS Comput Biol, 16, e1007701.

Liu W, Li Y, Li R, et al (2016). Association of MTHFR A1298C polymorphism with breast cancer and/or ovarian cancer risk an updatesd metanalysis. AJTCAM, 13, 72-86.

Liu XM, Liu FH, Tang Y, Li Q (2012). MTHFR C677T polymorphism and pancreatic cancer risk: a meta-analysis. Asian Pac J Cancer Prev, 13, 3763-66.

Moghaddam AS, Roodgar M, Mansourpour H, Jarrahi AM (2016). LSP1 gene rs3817198 polymorphism and breast cancer risk: a systematic review and meta-analysis study. Asian Pac J Cancer Biol, 1, 77-82.

Moghaddam AS, Roodgar M, Mansourpour H, Jarrahi AM (2018). Dominant and recessive genetic models of LSP1 gene rs3817198 polymorphism and breast cancer risk: A Systematic Review and Meta-analysis Study. Asian Pac J Cancer Biol, 3, 5-9.

Mir MM, Dar JA, Dar NA, et al (2008). Combined impact of polymorphism of folate metabolism genes; glutamate carboxypeptidase, methylene tetrahydrofolate reductase and methionine synthase reductase on breast cancer susceptibility in kashmiri women. Int J Health Sci (Qassim), 2, 314-21.

Nazki FH, Sameer AS, Ganaie BA (2014). Folate: metabolism, genes, polymorphisms and the associated diseases. Gene, 
533, 11-20.

Nie F, Yu M, Zhang K, et al (2020). Association of MTHFR gene polymorphisms with pancreatic cancer: meta-analysis of 17 case-control studies. Int J Clin Oncol, 25, 312-21.

Omran MH, Fotouh BE, Youssef SS, et al (2013). Association between low molecular polypeptide 7 single nucleotide polymorphism and response to therapy in hepatitis $\mathrm{C}$ virus infection. World Hepatol, 5, 97-103.

Omran MH, Ibrahim NE, Youssef SS, et al (2013). Relation of interleukin-1 $\beta$ gene to treatment response in chronic patients infected with HCV genotype 4. J Infect Develop Count, 7, 851-8.

Omran MH, Nabil W, Youssef SS, El-Sayed M, El Awady MK (2013). Heterogeneity and new epitopes of hepatitis $C$ virus genotype 4. Hepat Mon, 13, e10521.

Papandreou CN, Doxani C, Zdoukopoulos N, et al (2012). Evidence of association between methylenetetrahydrofolate reductase gene and susceptibility to breast cancer: a candidate gene association study in a South-Eastern European population. DNA Cell Biol, 31, 193-8.

Pepe C, Guidugli L, Sensi E, et al (2007). Methyl group metabolism gene polymorphisms as modifier of breast cancer risk in Italian BRCA1/2 carriers. Breast Cancer Res Treat, 103, 29-36.

Rahimi Z, Bozorgi M, Rahimi Z, et al (2019). MTHFR C677T polymorphism is associated with the risk of breast cancer among Kurdish population from western Iran. Int J Cancer Manag, 12, e67895.

Rai V, Yadav U, Kumar P, Yadav SK, Mishra OP(2014). Maternal methylenetetrahy-drofolate reductase $\mathrm{C} 677 \mathrm{~T}$ polymorphism and Down syndrome risk: a meta-analysis from 34 studies. PLoS One, 9, e108552.

Rakha EA, Ellis IO (2010). Lobular breast carcinoma and its variants. Semin Diagn Pathol, 27, 49-61.

Ramos-Silva A, Figuera LE, Soto-Quintana OM, et al (2015). Association of the C677T polymorphism in the methylenetetrahydrofolate reductase gene with breast cancer in a Mexican population. Genet Mol Res, 14, 4015-26.

Rezende LM, Marson FAL, Lima CSP, Bertuzzo CS (2017). Can MTHFR C677T and A1298C polymorphisms alter the risk and severity of sporadic breast cancer in Brazilian women? Clin Breast Cancer, 17, e199-e208.

Rozen R (1997). Genetic predisposition to hyperhomocysteinemia: deficiency of methylenetetrahydrofolate reductase (MTHFR). Thromb Haemost, 78, 523-6.

Said AF, Abulkheir IL, Helal A, Mohammad DB (2012). Detection of CK19 mRNA in the blood of breast cancer Female Egyptian patients and its relation to established prognostic parameters. Life Sci J Actazhenghou Univ Overseas Editioin, 9, 561-71.

Shaker OG, Senousy MA (2019). Association of SNP-SNP interactions between RANKL, OPG, CHI3L1, and VDR genes with breast cancer risk in Egyptian women. Clin Breast Cancer, 19, 220-38.

Siegel RL, Miller KD, Jemal A (2019). Cancer statistics, 2019. CA A Cancer J Clin, 69, 7-34.

Solé X, Guinó E, Valls J, Iniesta R, Moreno V (2006). SNPStats: a web tool for the analysis of association studies. Bioinform Oxf Engl, 22, 1928-9.

Song A, Zhao L, Li Y, et al (2016). Haplotypes of the MTHFR gene are associated with an increased risk of breast cancer in a Han Chinese population in Gansu province. IUBMB Life, 68, 526-34.

Veronesi U, Zurrida S, Viale G, et al (2009). Rethinking TNM: a breast cancer classification to guide to treatment and facilitate research. Breast $J, \mathbf{1 5}, 291-5$.

Waseem M, Hussain SR, Kumar S, et al (2016). Association of
MTHFR (C677T) gene polymorphism with breast cancer in North India. Biomark Cancer, 8, 111-7.

Weisberg I, Tran P, Christensen B, Sibani S, Rozen R (1998).A second genetic polymorphism in methylenetetrahydrofolate reductase (MTHFR) associated with decreased enzyme activity. Mol Genet Metab, 64, 169-72.

Weisberg IS, Jacques PF, Selhud J, et al (2001). The1298A $>$ C polymorphism in methylenetetrahydrofolate reductase (MTHFR): in vitro expression and association with homocysteine. Atherosclerosis, 156, 409-15.

Xia LZ, Liu Y, Xu XZ, et al (2014). Methylenetetrahydrofolate reductase $\mathrm{C} 677 \mathrm{~T}$ and $\mathrm{A} 1298 \mathrm{C}$ polymorphisms and gastric cancer susceptibility. World J Gastroenterol, 20, 11429-38.

Youssef SS, Mostafa A, Saad A, et al (2013). Impact of IL12B gene rs 3212227 polymorphism on fibrosis, liver inflammation, and response to treatment in genotype 4 Egyptian hepatitis C patients. Dis Markers, 35, 431-7.

Zhong R, Chen Q, Zhang X, et al (2019). Association between methylenetetrahydrofolate reductase (MTHFR) polymorphisms and lung cancer risk in Chinese people: An updated meta-analysis. Medicine (Baltimore), 98, e16037.

Zhong S, Chen Z, Yu X, et al (2014). A meta-analysis of genotypes and haplotypes of methylenetetrahydrofolate reductase gene polymorphisms in breast cancer. Mol Biol Rep, 41, 5775-85.

Zintzaras E, Lau J (2008). Synthesis of genetic association studies for pertinent gene-disease associations requires appropriate methodological and statistical approaches. J Clin Epidemiol, 61, 634-45.

\section{@ $0 \otimes$}

This work is licensed under a Creative Commons AttributionNon Commercial 4.0 International License. 